\title{
SPECIES AND BIOTYPE DISTRIBUTION OF THERMOTOLERANT CAMPYLOBACTERS IN ANIMAL RESERVOIRS IN SOUTHERN CHILE(')
}

\author{
Heriberto FERNANDEZ(2)
}

\begin{abstract}
SUMMARY
The prevalence of thermotolerant campylobacters in mammals and birds from Southern Chile was determined. Campylobacters were isolated from $46.3 \%$ of the animals studied being $\mathbf{C}$. jejuni biotipe 1 the most frequent $(25.7 \%)$ followed by $\mathbf{C}$. coli $(17.4 \%)$ and C. jejuni biotipe $2(3.2 \%)$.
\end{abstract}

KEY WORDS: Campylohacter; Campylobacteriosis; Reservoirs; Epidemiology.

\section{INTRODUCTION}

Thermotolerant campylobacters - Campylobacter jejuni and C. coli - are recognized as important agents of acute diarrheal illness in humans ${ }^{14,31}$. These microorganisms are widely distributed all over the world having as natural reservoirs a great variety of animal species including companion, domestic and wild animals $1,8,13,24$.

Human illness considered as zoonosis ${ }^{30} \mathrm{can}$ be acquired by contact with animals $9,20,30$, by drinking contaminated water with animal faeces $2,27,36$ or by ingestion of contaminated food of animal origin $2,20$.

In view of the lack of information about the natural distribution of thermotolerant campylobacters in this region of the world, a study was undertaken to determine the prevalence of $\mathbf{C}$. jejuni and $\mathbf{C}$. coli in different mammals and birds from southern Chile (province of Valdivia), southern latitude $39^{\circ} 15^{\prime}$ $-40^{\circ} 15^{\prime}$.

\section{MATERIALS AND METHODS}

A total of 631 fecal samples obtained by rectal swabs from 150 dogs, 80 pigs, 80 cows,
40 cats, 100 hens, 75 sparrows, 60 geese and 46 pigeons were studied. None of the animals subjeted to this study showed clinical symptoms of diarrhea. Rectal samples were obtained using commercial sterile swabs (Linsan Laboratories, Chile) supplied with a $1 \mathrm{ml}$ ampule of Cary Blair transport medium. After collection of the sample the ampules were crushed to moisten the swabs. Each sample was identified with an appropriate code number, and within 2 to 6 hours after collection were seeded on modified Skirrow's medium 26 comprising Brucella agar (Difco), 5\% horse blood, Skirrow's Antibiotic Supplement (Oxoid) plus $10 \mathrm{mg} / \mathrm{l}$ of cephalotin (Lilly) and FBP Supplement (Oxoid). Inoculated plates were incubated at $43^{\circ} \mathrm{C}$ for 48 hours under microaerobic conditions utilizing the Gas generating box Campylobacter system (bio Mérieux).

After the incubation period, the plates were examined for the presence of colonies presumed to be Campylobacter sp. The identification was made first presumptively ${ }^{17}$ using catalase and oxidase reactions (both positive) and the morphological features observed in Gram stain (curved S-shaped rods). Later, the Campylobacter species and biotypes were identified using the criteria propose by SKIRROW \& BENJAMIN ${ }^{33}$.

(1) Supported by research grant S-84-1 from the Research Fund of Universidad Austral de Chile.

(2) Institute of Clinical Microbiology. Universidad Austral de Chile. P.O. Box 567, Valdivia, Chile. 
FERNANDEZ, H. - Species and biotype distribution of thermotolerant Campylobacters in animal reservoirs in Southern Chile. Rev. Inst. Med. trop. São Paulo, 30(5):357-360, 1988

\section{RESULTS}

Campylobacters were isolated from 292 (46.3\%) of the animals studied The highest isolation rate was found in pigs $(70 \%)$, followed by hens $(60 \%)$ and dogs $(51.4 \%)$. The lowest rate was found in pigeons $(17.4 \%)$.

C. jejuni biotype 1 was the most frequently isolated $(25.7 \%)$ and was found in all the animals studied. C. coli was isolated from all the animals but not from cats and pigeons, with an average frequency of $17.4 \%$. C. jejuni biotype 2 was not round in hous, sparrows and pigeons and presented the lowest isolation rate $(3.2 \%)$. Table 1 shows the distribution of these campylobacters among the animal reservoirs studied.

TABIE 1

Distribution of thermotolerant campylobacters among various mammals and birds from soutinert. Chile.

\begin{tabular}{|c|c|c|c|c|c|c|c|c|c|}
\hline \multirow{2}{*}{\multicolumn{2}{|c|}{ A nimals studied ( $\mathrm{n}$ ) }} & \multicolumn{2}{|c|}{ C. jejuni biotype 1} & \multicolumn{2}{|c|}{ C. jejuni biotype 2} & \multicolumn{2}{|c|}{ C. coli } & \multicolumn{2}{|c|}{ Total } \\
\hline & & & $\%$ & No & $\%$ & NO & $\%$ & NO & $\%$ \\
\hline Dogs & $(150)$ & 46 & 30.7 & 6 & 4.0 & 25 & 16.7 & 77 & 51.4 \\
\hline Pigs & $(80)$ & 8 & 10.0 & 4 & 5.0 & 44 & 55.0 & 56 & 70.0 \\
\hline Cows & $(80)$ & 12 & 15.0 & 6 & 7.5 & 6 & 7.5 & 24 & 30.0 \\
\hline Cats & $(40)$ & 6 & 15.0 & 3 & 7.5 & 0 & 0.0 & 9 & 22.5 \\
\hline Hens & $(100)$ & 45 & 45.0 & 0 & 0.0 & 15 & 15.0 & 60 & 60.0 \\
\hline Sparrows & $(75)$ & 21 & 28.0 & 0 & 0.0 & 9 & 12.0 & 30 & 40.0 \\
\hline Geese & $(60)$ & 16 & 26.7 & 1 & 1.7 & 11 & 18.3 & 28 & 46.7 \\
\hline Pigeons & ( 46) & 8 & 17.4 & 0 & 0.0 & 0 & 0.0 & 8 & 17.4 \\
\hline Total & (631) & 162 & 25.7 & 20 & 3.2 & 110 & 17.4 & 292 & 46.3 \\
\hline
\end{tabular}

\section{DISCUSSION}

Birds and mammals constitute important links in the epidemiological chain of Campylobacter infections, 20. We studied several animal reservoirs that, according to their epidemiological relations with humans, can be divided in four groups:

1. companion animals (dogs and cats); 2 food animals (cows and pigs); 3 . poultry (hens and geese); 4. wild birds (sparrows and pigeons). Our results show that thermotolerant species of Campylobacter were present in high frequency in all of them.

C. jejuni biotype 1 was isolated from all the animals under study with an average frequency of $25.7 \%$. C. jejuni biotype 2 , with a frequency of $3.2 \%$, was found in all the animals but not in hens, sparrows and pigeons. With the exception of the cats and pigeons fecal samples, C. coli was isolated from the other animal feces with a frequency of $17.4 \%$. SKIRROW ${ }^{30-33}$ and SHANKER et al. ${ }^{28}$ reported that $\mathbf{C}$. jejuni biotype 1 was the most prevalent in fecal samples from hens and dogs. Our results support these findings. However they found that $\mathbf{C}$. jejuni biotype 2 was also frequent in these two animal species. C. coli was not isolated by SHANKER et al.28 from cloacal samples of hens. In our study $\mathbf{C}$. jejuni biotype 2 was found in low frequency $(4 \%)$ in dogs but not in hens. On the other hand, the prevalence of C. coli was $16.7 \%$ in dogs and $15 \%$ in hens. This results are very simmilar to that obtained by FERNÁNDEZ ${ }^{3}$ in fecal samples from dogs and hens in São Paulo - Brazil.

Some differences in the epidemiology of campylobacteriosis have been established among developed and developing countries such as the high percentage or normal carriers and a greater frequency of cases in the first two years of life observed in the latter countries 4,5 .

The fact that $\mathbf{C}$. jejuni biotype 2 is less and $\mathbf{C}$. coli more frequent in hens and dogs in Brazil ${ }^{3}$ and southern Chile, could be considered a peculiar epidemiological situation observed in developing countries. However, more data must be made available from third world countries to establish definitively this statement.

The prevalence of Campylobacter in dogs $(51.4 \%)$ was higher than that obtained by 
FERNANDEZ, H. - Species and biotype distribution of thermotolerant Campylobacters in animal reservoirs in Southern Chile. Rev. Inst. Med. trop. São Paulo, 30(5):357-360, 1988

McORIST \& BROWNINGis in Australia $(9.5 \%)$ and JORGENSEN 12 in Denmark $(11.1 \%)$. Nevertheless, it was simmilar to that reported by SIMPSON et al.29 in stray dogs $(52.6 \%)$ in England. Remarkable differences exist in the incidence of intestinal carriage of Campylobacter among stray and pet $\operatorname{dog} s^{2,}, 29,30$. Although all the dogs studied had an individualized owner, many of them presented loiterer habits reflecting a poor standard of canine hygiene that predisposes to intestinal colonization with Campylobacter ${ }^{30}$.

The prevalence of Campylobacter in cats $(22.5 \%)$ was higher than that reported by McORIST \& BROWNING'19 in Australia (3\%) and by PATTON et al.22 in U.S.A. (14\%). Because the cats studied presented the same habits observed in the dogs (owners references) we can use the same considerations as SKIRROW 30 to explain the high isolation rates of Campylobacter obtained in both animal species. These results constitute another evidence of the importance of dogs and cats as natural reservoirs of Campylobacter as potencial sources for human infections $2,9,20,24,30$.

The fecal carriage of Campylobacter in pigs $(\mathbf{7 0 \%})$ was very simmilar to that reported by STICHT-GROH ${ }^{34}$ in Germany $(77 \%)$ and LUECHTEFELD \& WANG 16 in U.S.A. $(71 \%)$, but lower to that published by ROSEF et al. 25 in Norway $(100 \%)$. The fact that $\mathrm{C}$. coli forms part of the normal intestinal flora of pigs $^{3}$ explains the high isolation frequency of this bacteria $(55 \%)$ in the pigs subjected to our study.

Campylobacter was found in $30 \%$ of the cows under study. This result is lower than reported by LUECHTEFELD \& WANG 16 in U.S.A. $(43 \%)$ but higher than the results obtained by SWEDHEM \& KAIJSER ${ }^{35}$ in Sweden (19\%).

The isolation of thermotolerant species of Campylobacter in high frequency from these two animals indicate their importance as natural reservoirs and sources of these bacteria for man. Humans can acquire the infection by contact with these animals 9,20 or by consumption of contaminated meats and milk $2,10,20,23$.

In hens and geese the Campylobacter isolation rate was $60 \%$ and $46.7 \%$ respectively. High isolation rates of Campylobacter from both, slaughtered and alive hens, is a common fact in many countries 2,6 . Wild geese harbour these microorganisms frequently in their intestinal tract 15 .

Poultry constitutes an important vehicle of Campylobacter and the role of poultry meat in the illness transmission is well established 2, 10, 11 .

The isolation rate of Campylobacter in sparrows was $40 \%$. The corresponding values found by MATSUSAKI et al. ${ }^{18}$ in Japan was only $10 \%$ whereas, KAPPERUD \& ROSEF ${ }^{13}$ did not isolated any Campylobacter from sparrows in Norway.

In pigeons we isolated only $C$. jejuni biotype 1 with a frequency of $17.4 \%$ MATSUSAKI et al.18 and KAPPERUD \& ROSEF 13 reported $7 \%$ and $4.2 \%$ of intestinal carriage of Campylobacter in pigeons respectively. WEBER et al. ${ }^{37}$ in Germany, demonstrated that Campylobacter can be isolated with high frequency $(54.9 \%)$ from carrier pigeons. Sparrows and pigeons are wild birds that can live near man and may be sources of contamination for water supplies and the environment as it has been previously suggested 7.21 .

Except for studies on pigs and hens 6,7 , this work is the first study in Chile to ascertain the prevalence of thermotolerant campylobacters in animals. We think that more studies are necessary to understand the epidemiology of campylobacteriosis that seems to be a very complex phenomenon in developing countries.

\section{RESUMO}

Espécies e biotipos de Campylobacter termotolerantes em reservatórios animais do sul do Chile.

Foi determinada a prevalência de Campylobacter termotolerantes em mamíferos e aves do sul do Chile.

Campylobacter foi isolado em $46,3 \%$ dos animais estudados sendo $\mathbf{C}$. jejuni biotipo 1 o mais frequente $(25,7 \%)$ seguido de $\mathbf{C}$. coli $(17,4 \%)$ e C. jejuni biotipo $2(3,2 \%)$.

\section{REFERENCES}

1. BLASER, M.J.; LA FORCE, F.M.; WILSON, N.A. \& WANG, W.L.L. - Reservoirs for human campylobacteriosis. J. infect. Dis., 14:665-669, 1980.

2. BLASER, M.J.; TAYLOR, D.N. \& FELDMAN, R.A. - Epidemiology of Campylobacter jejuni infections. Epidem. Rev., 5:157-176, 1983

3. FERNANDEZ, H. - Thermophilic species of Campy- 
FERNANDEZ, H. - Species and biotype distribution of thermotolerant Campylobacters in animal reservoirs in Southern Chile. Rev. Inst. Med. trop. São Paulo, 30(5):357-360, 1988.

tobacter: bacteriological, epidemiological and pathogenical aspects. São Paulo, 1983. (Doctoral Thesis School of Medicine).

4. HERNANDEZ, H.; TOLEDO, M.R.F.; FAGIUNDES NETO, U.\& TRABULSI, L.R. - Isolation of Campylobacter jejuni in children with acute diarrhoea and in healthy controls. Rev. méd. Chile, 122:238-241, 1984

5. FERNANDEZ, H.; TOLEDO, M.R.F.; FACIUNDES NETO, U. \& TRABULSI, L,R. - Occurrence of Campylobacter jejuni in diarrhoeic and non-diarrhocic children in São Paulo, Brazil. Rev. Inst. Med. trop. S. Paulo, 27:102-104, 1985.

6. FIGUEROA, G.; TOLEDO, M.S.; TRONCOSO, M. \& SEPUIVEDA, C. - Isolation of Campylobacter fetus subsp. jejuni from broiler chickens. Rev, chil. Nutr., 10:87.98, 1982.

7. FIGUEROA, (j.; TRONCOSO, M.; ALCAYDE, M.P. \& SEPULVEDA, C. - Isolation of Campylobacter fetus subsp. jejuni from fecal samples of pigs. Rev. chil. Tecnol. méd., 4:6-10, 1980.

8. FOX, J.G. - Campylobacteriosis. A "new" disease in laboratory animals. Lab. Anim. Sci., 32:625-637, 1982.

9. FOX, J.G.; MOORE, R. \& ACKFRMANN, J.I. Canine and feline campylobacteriosis: Epizootiology and clinical and public health features. J. Amer. vet. med. Ass., 183: 1420-1424, 1983.

10. HARRIS, N.V.; WEISS, N.S. \& NOLAN, C.M. The role of poultry and meats in the etiology of Campylobacter jejuni/coli enteritis. Amer. J. publ. Hith., 76:407-411, 1986.

11. HOPKINS, R. \& SCOTT, A.S. - Handling raw chicken as a source for sporadic Campylobacter jejuni infections. J. infect. Dis., 148:770, 1983.

12. JORGENSEN, K. - Prevalence of Campylobacter fetus subsp. jejuni in Danish dogs. Nord. Vet. - Med., $33: 42-48,1981$.

13. KAPPERUD, G. \& ROSEF, O. - Avian wildlife reservoirs of Campylobacter fetus subsp. jejuni, Yersinia spp., and Salmonella spp. in Norway. Appl. environ. Microbiol., 45:375-380, 1983.

14. LEVIN, S. \& GOODMAN, L. - Campylobacter infections today. J. Amer. med. Ass., 253:1303, 1985.

15. LUECHTEFELD, N.A.W.; BLASER, M.J.; RELLER, L.B. \& WANG, W.L.L. - Isolation of Campylobacter fetus subsp. jejuni from migratory waterfowl. J. clin. Microbiol., 12:406-408, 1980.

16. LUECHTEFELD, N.W. \& WANG, W.L.L. - Animal reservoirs of Campylobacter jejuni. In: NEWEL, D.G., ed. - Campylobacter: epidemiology, pathogenesis, biochemistry. Lancaster, M.T.P. Press, 1982. p. 249-251.

17. LUECHTEFELD, N.W.; WANG, W.L.L.; BLASER, H.J. \& RELLER, L.D. - Campylobacter fetus subsp. jejuni: background and laboratory diagnosis. Lab. Med., 12:481-487, 1981

18. MATSUSAKI, S.; KATAYAMA, A. \& ITAGAKI, K. - Prevalence of Campylobacter jejuni and $C$. coli in wild birds and domestic animals in Yamaguchi, Japan. In: INTERNATIONAL WORKSHOP ON Campylobacter INFECTIONS, 3rd., Ottawa, Canada, 1985. Abstract. Abstr. No 160.

19. MCORIST, S. \& BROWNING, J.W. - Carriage of Campylobacter jejuni in health and diarrhoeic dogs and cats. Aust. vet. J., 58:33-34, 1982.

20. MEGRAUD, F. \& LATRILLE, J. -- Campylobacter jejuni en pathologie humaine. II. Diagnostic biologique et épidemiologie. Path. et Biol., 29:305-314, 1981.

21. PALMER, S.R.; GULLY, P.R.; WHITE, J.M.; PEARSON, A.D.; SUCKLING, W.G.; JONES, D.M.; RAWES, J.C.L. \& PENNER, J.L. - Waterborne outbreak of Campylobacter gastroenteritis. Lancet, 1:287-290, 1983.

22. PATTON, C.M.; MITCHELL, S.W ; POTTER, M.E. \& KAUFFMANN, A.F. - Comparison of selective media for primary isolation of Campylobacter fetus subsp. jejuni. J. clin. Microbiol., 13:326-330, 1981.

23. POTTER, M.E.; BLASER, J.M.; SIKES, R.K.; KALFFMANN, A.F. \& WELLS, J.G. - Human Campylobacter infection associated with certified raw milk. Amer. J. Epiden., 117:475-483, 1983.

24. PRESCOTT, I.F. \& MUNROE, D.I. - Campylobacter jejuni in man and domestic animals. J. Amer. vet. Med. Ass., 181:1524-1530, 1982 .

25. ROSEF, O.; GONDROSEN,B.; KAPPERUD, G. \& UNDERDAL. B. - Isolation and characterization of Campylobacter jejuni and Campylobacter coli from domestic and wild mammals in Norway. Appl. environ. Microbiol., 46:855-859, 1983

26. SACK, R.B.; TILTON, R.C.\& WEISSFELD, A.S. Laboratory diagnosis of bacterial diarrhea. Amer. Soc. Microbiol. Cumitech, 12:1-12, 1980.

27. SACKS, J.J.; LIEB, S.; BALDY, L.M.; BERTA, S.; PATTON, C.M.; WHITE, M.C.; BIGLER, W.J. \& WITTE, J J. - Epidemic campylobacteriosis associated with a community water supply. Amer. J. publ. HIth. 76:424-429, 1985.

28. SHANKER, S.; ROSENFIELD, J.A.; DAVEY G.R. \& SORRELL, T.C. - Campylobacter jejuni: incidence in processed broilers and biotype distribution in human and broiler isolates. Appl. environ. Microbiol., 43:1219-1220, 1982.

29. SIMPSON, J.W.; BURNIE, A.G.; FERGUSON, S.\& TELFER, W.A.B. - Isolation of thermophilic Campylobacter from two populations of dogs. Vet. Res. Comm., 5:63-66, 1981 .

30. SKIRROW, M.B. - Campylobacter enteritis in dogs and cats: a "new" zoonosis. Vet. Res. Comm., 5:13$19,1981$.

31. SKIRROW, M.B. - Campylobacter enteritis: the first five years. J. Hyg. (Lond.), 89:1975-1984, 1982.

32. SKIRROW, M.B. - Epidemiological aspects of Campylobacter enteritis. In: NEWEL, D.G., ed. Campylobacter I. London, Public Health Laboratory Service, 1982. p.67-69.

33. SKIRROW, M.B. \& BENJAMIN, J. - Differentiation of enteropathogenic Campylobacter. J. clin. Path., 33:1122,1980.

34. STICH-GROH, V. - Campylobacter in healthy slaughter pigs: a possible source of infection for man. Vet. Rec., 110:104, 1982.

35. SVEDHEM, A. \& KAIJSER, B. - Campylobacter jejuni from domestic animals and pets: probable origin of human infection. J. Infect., 3:37-40, 1981.

36. VOGR, R.L., SOURS, H.E.; BARRET, T.; FELDMAN, R.A.; DICKINSON R.J. \& WITHEREILL, L. - Campylobacter enteritis associated with contaminated water. Ann. intern. Med., 96:292-296, 1982.

37. WEBER, V.A.; LEMBKE, C. \& KETTNER, A. - Occurrence of Campylobacter jejuni in faecal samples of clinically healthy carrier pigeons. Berl. Münch. tierärztl. Wschr., 94:449-451, 1981.

Recebido para publicação em 22/3/1988. 